NBER WORKING PAPER SERIES

\title{
WHEN WALMART COMES TO TOWN: ALWAYS LOW HOUSING PRICES? ALWAYS?
}

\author{
Devin G. Pope \\ Jaren C. Pope \\ Working Paper 18111 \\ http://www.nber.org/papers/w18111
NATIONAL BUREAU OF ECONOMIC RESEARCH
1050 Massachusetts Avenue
Cambridge, MA 02138

May 2012

We thank Emek Basker, Nick Kuminoff, Lars Lefgren, and Arden Pope as well as colleagues at the University of Chicago and Brigham Young University for helpful discussions about this paper. We also thank Chris Bruegge and Brendan Forster for excellent research assistance on this project. The standard disclaimer applies. There were no sources of funding or material and relevant financial relationships for this project. The views expressed herein are those of the authors and do not necessarily reflect the views of the National Bureau of Economic Research.

NBER working papers are circulated for discussion and comment purposes. They have not been peerreviewed or been subject to the review by the NBER Board of Directors that accompanies official NBER publications.

(C) 2012 by Devin G. Pope and Jaren C. Pope. All rights reserved. Short sections of text, not to exceed two paragraphs, may be quoted without explicit permission provided that full credit, including $\odot$ notice, is given to the source. 
When Walmart Comes to Town: Always Low Housing Prices? Always?

Devin G. Pope and Jaren C. Pope

NBER Working Paper No. 18111

May 2012

JEL No. R20

\begin{abstract}
$\underline{\text { ABSTRACT }}$
Walmart often faces strong local opposition when trying to build a new store. Opponents often claim that Walmart lowers nearby housing prices. In this study we use over one million housing transactions located near 159 Walmarts that opened between 2000 and 2006 to test if the opening of a Walmart does indeed lower housing prices. Using a difference-in-differences specification, our estimates suggest that a new Walmart store actually increases housing prices by between 2 and 3 percent for houses located within 0.5 miles of the store and by 1 to 2 percent for houses located between 0.5 and 1 mile.
\end{abstract}

Devin G. Pope

Booth School of Business

University of Chicago

5807 South Woodlawn Avenue

Chicago, IL 60637

and NBER

devin.pope@chicagobooth.edu

Jaren C. Pope

Brigham Young University

Department of Economics

jaren_pope@byu.edu 


\section{Introduction}

One of the most significant changes over the past two decades in the U.S. retail market is the expansion of large box stores and supercenters. Walmart is the largest of these rapidly growing retailers and is currently the biggest private employer in the world. In the United States alone, Walmart currently operates more than 4,400 retail facilities and employs almost 1.4 million people. ${ }^{1}$ Phone surveys suggest that $84 \%$ of households in the U.S. shop at Walmart in a given year with $42 \%$ of households reporting to be regular Walmart shoppers (Pew Research Center, 2005). These surveys also show that lower-income households are more likely to shop at Walmart than upper-income households. In fact, Basker, (2005b), Hausman and Leibtag (2007), and Basker and Noel (2009) have shown that Walmart "Supercenters" that sell groceries offer many identical food items as other grocers at an average price that is substantially lower than their competitors. Hausman and Leibtag (2007) also find that these lower prices translate into a significant increase in consumer surplus.

Despite the consumer benefits from the expansion of supercenters into new geographic markets, there is often significant opposition and controversy when Walmart tries to open a new store. One concern of opponents is the impact that a new Walmart will have on local employment opportunities and wages. There is a small literature that has analyzed this common concern including Basker (2005a), Hicks (2007a) and Neumark et al. (2008). The findings of these studies have been mixed with Basker (2005a) and Hicks (2007a) finding positive effects on employment and/or wages, while

\footnotetext{
${ }^{1}$ These numbers were taken from the August 2011 fact sheet provided on the Walmart website and can be found at http://walmartstores.com/pressroom/factsheets/
} 
Neumark et al. (2008) found negative effects. ${ }^{2}$ Another primary concern of opponents to a new Walmart, is the effect it will have on crime, traffic and congestion, noise and light pollution, the visual aesthetics of the local area, and ultimately the impact that these externalities will have on local housing prices. ${ }^{3}$ However, unlike the academic literature that surrounds the labor-market effects of Walmart, there has been no peer-reviewed work that attempts to understand the impact of Walmart on housing prices. ${ }^{4}$

In this paper we try to understand if building a new Walmart has a positive or negative effect on nearby housing prices. Answering this question is important as citizens and local governments grapple with the economic impacts of allowing Walmart to build a new store in their jurisdiction. Analyzing housing prices is a particularly useful way to understand the economic value of a Walmart entering a community. For example, when a Walmart is built, it generally is not built in isolation. The Walmart store often acts as a hub that attracts a variety of other businesses, which in turn, can also have impacts on housing markets. If households value convenient access to the goods and services that Walmart and these other businesses provide, then the new stores would have a positive impact on housing prices. However, if Walmart and the businesses that agglomerate

\footnotetext{
${ }^{2}$ The different findings in these studies depend primarily on the identification strategy employed to account for the potential endogeneity of the location and timing of Wal-Mart openings. See Basker (2007) and Neumark et al. (2008) for a discussion of these differences.

${ }^{3} \mathrm{An}$ example of these concerns can be seen in a document created by the non-profit community organization called "Responsible Growth for Northcross." This group was formed to oppose a Walmart supercenter being built near the Northcross mall in Austin, Texas. They made a top 10 list for why Walmart shouldn't be built in their town. Number two on their list was that "Wal-Marts Lower Prices. Including your property value." The full list can be found at http://corpethics.org/downloads/northcross_no_walmart.pdf

${ }^{4}$ There is a paper on the impact of Walmart on annual property tax collections and commercial properties by Hicks (2007b) and a working paper by Vandegrift, Loyer, and Kababik (2011). There is also a small but growing literature on the impact of Walmart on a variety of other outcomes outside of labor and housing markets. These include poverty rates (Goetz and Swaminathan, 2006), small business activity (Sobel and Dean, 2008), obesity (Courtemanche and Carden, 2011), social capital (Goetz and Rupasingha, 2006; Carden et al., 2009a), leisure activities (Carden and Courtemanche, 2009) and traditional values (Carden et al., 2009b).
} 
nearby also impose negative externalities such as increased pollution, crime, and traffic, then this could adversely impact prices of nearby houses. Thus the housing price effect $a$ priori is ambiguous. Accurately estimating the housing price changes that result from the building and opening of a Walmart and the agglomeration it spurs may help local policymakers to better understand if the net effect of a new Walmart is perceived as beneficial to nearby households. This could in turn provide some economic justification for a local government to encourage or discourage the building of a Walmart store in its jurisdiction.

Our analysis of the impact that Walmart has on housing prices utilizes two unique datasets. The first dataset describes when and where Walmarts opened between 2000 and 2006. The second dataset includes data for more than one million residential housing transactions that occurred within four miles of 159 Walmarts that opened during this time period. In contrast to the county-level analyses conducted by most previous work on the impacts of Walmart, the micro-level nature of our dataset allows us to develop an identification strategy that can help us to overcome the potential endogeneity of the location and timing of Walmart openings. More specifically, we employ a difference-indifferences analysis that compares housing prices before and after a Walmart opens for areas very close to a newly built Walmart, to areas slightly farther away.

The results from this analysis suggest that a new Walmart store increases nearby housing prices. Our primary analysis suggests that houses located within 0.5 miles of the store see increases in their prices of about 2-3 percent when comparing the two and a half years before the Walmart opened to the two and a half years after the opening. Houses between 0.5 and 1 mile from the Walmart see an increase of 1-2 percent. It does not 
appear that these price impacts are caused by an abrupt increase in the number of houses that sold in the area or by a change in the composition of houses that sold. Furthermore, graphical evidence and falsification tests provide no evidence of a spurious, positive effect due to differential housing price growth at the Walmart location and are therefore supportive of a causal interpretation of our difference-in-differences estimates of the impact of Walmart on housing prices.

The paper proceeds as follows. In section 2 we discuss the potential impacts of Walmart in terms of the value of accessibility and the costs of negative externalities. We proceed in section 3 to describe the key datasets used in our analysis. In section 4, we describe our empirical strategy for estimating the impact of Walmart on housing prices and in section 5, we present the results. Finally, we conclude in section 6.

\section{Accessibility and Externality Effects of Walmart}

Walmart likely affects housing prices through two main channels_accessibility and negative externalities. Many studies at the intersection of economics and geography have shown that land and housing prices vary with accessibility to "business districts" that provide shopping and employment. For example, the American Housing Survey (AHS), which is constructed by the U.S. Census Bureau and is based on household surveys that are aimed at better understanding the determinants of housing values throughout the United States, specifically asks households if there is "satisfactory shopping within 1 mile." Using this data, Emrath (2002) provided evidence that having satisfactory shopping within one mile increased housing prices substantially inside metro areas. Others, including Sirpal (1994) and Des Rosiers et al. (1995), have also found a 
positive correlation between shopping centers and housing prices. These studies suggest that having convenient access to a Walmart might increase housing prices.

On the other hand, the introduction of a Walmart store in a community also has the potential to lower housing prices through increased local crime, noise and light pollution, traffic congestion, garbage accumulation, and loss of perceived visual aesthetics. Several studies have shown that these disamenities are capitalized into housing prices. For example, Linden and Rockoff (2008) and Pope (2008) have both recently shown that a discrete change in the risk of a localized crime can have a causal impact on housing prices, Smith et al. (2002) showed that freeway noise can have a negative impact on housing prices, and Lim and Missios (1995) showed the negative impact of landfills on housing prices.

An important question that has not been addressed in the literature is whether or not the benefits of access to a Walmart outweigh the costs imposed by any negative externalities that it imposes on the local community when it builds a store. Analyzing housing prices before and after a Walmart is built in a given locale offers the potential to test whether or not the benefits of accessibility outweigh the costs of negative externalities. If one were to see a decrease in housing prices near a Walmart store after it was built, this might signal that there are significant negative externalities imposed on landowners and households nearby Walmart. However, if one were to see an increase in housing prices, this might suggest that the benefits of easy access to Walmart's lower prices or the other shopping that naturally agglomerates near a Walmart outweigh any negative externalities imposed on local residents. 
There is some evidence that the value of accessibility declines less rapidly across space than the costs of localized externalities. Li and Brown (1980) provide empirical evidence to suggest that although proximity to industry and commercial areas impose negative externalities on nearby houses, this same proximity creates substantial benefits to households far enough away to avoid the sphere of influence from the negative externalities. In the next sections we examine the impact of building Walmart stores on surrounding housing prices to test whether the benefits of accessibility to Walmart outweigh the costs of negative externalities that Walmart may impose.

\section{Data}

The analysis relies on two key datasets. The first is data on Walmart stores that opened over the relevant time frame of our study. The second is data on single family residential properties in areas where the Walmart stores opened. In this section we describe each source of data in preparation for our empirical analysis.

\subsection{Walmart Data}

The Walmart data includes the address and opening dates of regular Walmart stores and Walmart supercenters in the United States. ${ }^{5}$ The original data contain the full universe of Walmart stores that were built between 1962 and Jan. 31, 2006. However, because of housing data constraints, we focus on 159 stores that were built between July 2000 and January 31, 2006 for which we have corresponding housing data. Table 1

\footnotetext{
${ }^{5}$ The data was generously provided to us by Thomas J. Holmes of the University of Minnesota and was used in his paper, Holmes (2011). The data and additional information on how the data were collected can be found at Professor Holmes' website at: http://www.econ.umn.edu/ holmes/research.html
} 
provides summary statistics for this dataset over time and space. Panel A shows the years in which the 159 Walmarts in our primary sample were built. It may seem curious that there were 9 stores built in 2006 when our dataset ends January 31, 2006. However, Panel B of Table 1 shows that January is the most common month for Walmarts to open. This is because January $31^{\text {st }}$ is considered the end of Walmart's fiscal year and so it appears there is a push to open new Walmarts before this date. Panel C shows the twenty U.S. states in our primary sample in which Walmarts were built.

We also collected some additional information on when it was announced that these Walmarts were to be built. This information was collected using the internet to find newspaper articles or other online sources that indicated the timing of when the building of a particular Walmart was announced to the community. After collecting these dates, we found that the median number of days from when the Walmart store was announced until its construction was completed and the Walmart store was open for business was 516 days. This information is useful in our analysis to help determine the appropriate size of the temporal window in which to analyze the housing price effects from a Walmart opening. The announcement information is also useful for explicitly estimating if there are price effects from the announcement itself.

\subsection{Housing Price Data}

Our analysis is based on a large housing dataset of more than one million observations on the sales of single-family residential properties across the United States between January 1, 1998 and January 31, 2008. We purchased the data from a commercial vendor who had assembled them from assessor's offices in individual towns 
and counties. ${ }^{6}$ The data include the transaction price of each house, the sale date, and a consistent set of structural characteristics, including square feet of living area, number of bathrooms, number of bedrooms, year built, and lot size. Using these characteristics, we performed some standard cleaning of the data, removing outlying observations, removing houses built prior to 1900, and removing houses built on lots larger than 5 acres.

The data also include the physical address of each house, which we translated into latitude and longitude coordinates using GIS street maps and a geocoding routine. The lat-long coordinates were then used to determine the distance of each house to the nearest Walmart location. In our primary analysis we restrict the data to include only those houses that are within four miles of a Walmart and that sold in the two and a half years before the nearest Walmart opened or in the two and a half years after it opened. ${ }^{7}$ Table 2 provides summary statistics of our primary housing dataset. The first column reports the summary statistics for the over 600,000 housing transactions between 1998 and 2008 that will be used in our primary analysis. The average sale price, square footage, \# of baths, age, lot size, and number of bedrooms in our full sample of homes was approximately 267,000 dollars, 1,767 square feet, 2 baths, 30 years old, 0.25 acres and 3 bedrooms respectively. Also, about $15 \%$ of houses in our sample of transactions were newly constructed, approximately $2 \%$ are located within 0.5 miles of where a Walmart has or will be built, $7 \%$ are located between 0.5 and 1 mile, and $25 \%$ between 1 and 2 miles. ${ }^{8}$ The columns labeled " 1 to 2 miles", " 0.5 to 1 mile" and "within 0.5 mile" provide summary statistics for houses within these distances to where a Walmart has or will be built. The summary statistics indicate that, houses closer to a Walmart tend to be smaller in size, somewhat newer, and on slightly smaller lots. These small differences in housing

\footnotetext{
${ }^{6}$ The commercial data vendor is Dataquick whose housing data is often used for academic research.

${ }^{7}$ A four mile radius was chosen a priori following Holmes (2011) assumption that houses within 2 miles are considered within the Walmart's "neighborhood." Houses between two and four miles were included in our sample to act as a natural control group.

${ }^{8}$ A house was defined as new construction if the year it sold was the same year it was reportedly built or the year after it was built.
} 
characteristics suggest that new Walmarts were not built in random locations. The endogenous placement of Walmarts motivates the empirical strategy that we outline below.

\section{Empirical Strategy}

\subsection{Hedonic Pricing Method}

When a household chooses to purchase a house, it is choosing more than just housing characteristics; it is also choosing a bundle of locational characteristics such as school quality, levels of criminal activity, proximity to work, and access to shopping. The hedonic model was developed by Rosen (1974) to provide a theoretical foundation for the relationship between prices and attributes. For over 40 years economists have used the hedonic pricing method in conjunction with the housing market to reveal household preferences for important locational characteristics. $^{9}$

Early work in this area typically used cross-sectional data to try and identify the implicit price of the locational attribute of focus. The primary concern with this literature has been the possibility that omitted variables lead to a bias in the estimates for key implicit prices. For example, if Walmarts tend to be built in areas where there is higher crime, then a cross-sectional estimate of the implicit price for living near a Walmart that excludes the relevant measures of crime will be biased downwards (more negative). Recognizing the importance of mitigating this type of omitted variable bias, a new wave of hedonic analyses have exploited quasi-experiments in time and/or space to better overcome omitted variable bias and identify implicit prices of interest. Examples of this

\footnotetext{
${ }^{9}$ Ridker and Henning's (1967) study on the value of air quality is one of the earliest examples in this literature. See Palmquist (2005) for a more complete review of the hedonic method applied to housing markets.
} 
new wave of quasi-experimental hedonic research include Black (1999), Figlio and Lucas (2004), Chay and Greenstone (2005), Pope (2008) and Linden and Rockoff (2008), among others. ${ }^{10}$

A quasi-experiment that exploits a temporal shock to better "difference" away time-invariant omitted variables is not without some costs as was recently pointed out in a paper by Kuminoff and Pope (2012). A large exogenous shock to the spatial distribution of a nonmarket $\operatorname{good}(\mathrm{s})$ may also cause the hedonic price function to adjust in order to clear the market. If this occurs, comparing implicit prices of the nonmarket good before and after the shock (the capitalization effect) may not correspond to the change in the willingness to pay for the nonmarket good (the welfare effect). Thus the quasiexperimental capitalization effects we estimate in section 5 may not have an exact welfare theoretic interpretation (though the estimates may be suggestive of the sign and magnitude). While the estimates may not be directly useful for a strict welfare-theoretic, benefit-cost analysis of the impact of the placement of a Walmart in a community, they can still be useful to homeowners, renters, assessors, appraisers, and the beneficiaries of programs funded by property tax revenue in areas where Walmarts are built, since they describe the size and sign of the capitalization effect on housing prices.

The work presented in this study builds off of this quasi-experimental literature in the construction of an identification strategy to understand the impact of Walmart openings on housing prices. However, we begin by constructing a traditional hedonic specification for the analysis. The most basic hedonic price specification that we employ takes the following cross-sectional form:

\footnotetext{
${ }^{10}$ See Parmeter and Pope (2012) for a more detailed review of the quasi-experimental method applied to housing and hedonic models.
} 


$$
\log \left(P_{i j y m}\right)=\alpha_{j y m}+\gamma \mathbf{X}_{i}+\beta_{0} D_{i j}^{0.5}+\theta_{0} D_{i j}{ }^{1}+\phi_{0} D_{i j}{ }^{2}+\varepsilon_{i j y m}
$$

The log of the sale price of the house is a function of a store $(j)$ by year $(y)$ by month $(m)$ specific effect $\left(\alpha_{j y m}\right)$, observable individual $(i)$ property characteristics $\left(\mathbf{X}_{i}\right)$, indicator variables of individual houses within $0.5,0.5$ to 1 , and 1 to 2 miles of a Walmart where the omitted indicator variable is an indicator for homes between 2 and 4 miles from the nearest Walmart $\left(D_{i j}{ }^{0.5} ; D_{i j}{ }^{1} ; D_{i j}{ }^{2}\right)$ and a random error term that allows for year by month by store area specific correlation in housing prices $\left(\varepsilon_{i j y m}\right)$. Absent any omitted variable bias and using only houses that sold after the nearest Walmart was built, estimation of Equation 1 will yield estimates of the key parameters $\left(\hat{\beta}_{0} ; \hat{\theta}_{0} ; \hat{\phi}_{0}\right)$ that show the impact that being near a Walmart has on housing prices for homes within $0.5,0.5$ to 1 , and 1 to 2 miles of a Walmart relative to homes that are 2 to 4 miles from the store. ${ }^{11}$ This estimation strategy can be considered the "traditional" cross-sectional hedonic approach.

A traditional approach to analyzing the impact that Walmart has on housing prices may of course be plagued with omitted variable bias. Another hedonic specification that could be used to help overcome the omitted variable bias would be a spatial differencein-differences specification of the following form:

$$
\log \left(P_{i j y m}\right)=\alpha_{j y m}+\gamma \mathbf{X}_{i}+\beta_{0} D_{i j}{ }^{0.5}+\theta_{0} D_{i j}{ }^{1}+\phi_{0} D_{i j}{ }^{2}+\left(\beta_{1} D_{i j}{ }^{0.5}+\theta_{1} D_{i j}{ }^{1}+\phi_{1} D_{i j}{ }^{2}\right) * \text { Post }_{i y m}+\varepsilon_{i j y m}
$$

The key difference between Equation (2) and Equation (1) is that we are exploiting the timing of the opening of the Walmart. To estimate Equation (2), housing data near a

\footnotetext{
${ }^{11}$ This is of course assuming that the correct functional form is being used as well as other underlying assumptions for linear regression hold.
} 
Walmart both before and after the opening of the Walmart store would be used. The key parameters in this specification are the estimates for the spatial indicators $\left(\hat{\beta}_{1} ; \hat{\theta}_{1} ; \hat{\phi}_{1}\right)$ that have been interacted with an indicator for whether the housing transaction took place after the Walmart was opened $\left({ }^{P o s t} t_{i y m}\right)$. These parameters give us the local effect on the treated spatial zones. $^{12}$

The key advantage of the difference-in-differences specification is that by including spatial fixed effects and looking at housing prices before and after the opening of Walmarts, we can difference away time-invariant omitted variables that could bias our estimates. However, we must rely on the identifying assumption that housing price trends for areas near the Walmart and those areas slightly farther away from the Walmart would have been the same had the Walmart store (and any other stores from the agglomeration effect) not been built. This assumption would be less attractive if we were using countylevel averages of housing prices to make comparisons between "treated" counties and "control" counties. As discussed earlier, much of the literature on the labor market effects relied on county-level measures for their analyses. This is why, for example, Basker (2005a) and Neumark (2008) relied on instrumental variable strategies to deal with the endogeneity of Walmart location decisions. In our analysis, instead of needing housing price trends in treatment and control counties to be the same before and after Walmart is built, all we need is housing price trends to be the same in the four mile zone surrounding the Walmart. Given that the area of a circle with a radius of 4 miles is approximately $1 / 12^{\text {th }}$ of the area of the median county in the U.S., exploiting the miro-level housing data

\footnotetext{
${ }^{12}$ The estimates generated from this specification are clearly for the houses near the Walmarts in our sample and may not be externally valid, for example, in very rural areas for which we do not have housing transactions.
} 
in this way is very attractive. ${ }^{13}$ Furthermore, the micro-level housing data allows us to explore any change in the rate at which houses sold or a change in the composition of houses that sold after Walmart was announced or built that could affect the interpretation of our estimates. Furthermore, the micro-level housing data allows us to look at housing price trends graphically and also to conduct falsification tests by shifting the Walmart open dates forward. We explore the housing composition issue and do both of the checks on the validity of our key identifying assumption in the difference-in-differences framework in the results section.

\section{Results}

\subsection{Cross-Sectional Results}

We first describe the results from estimating a "traditional" cross-sectional hedonic analysis following Equation (1) above. The housing data used in this regression are restricted to approximately 358,000 houses within four miles of a Walmart that sold in the two and a half years after the Walmart was built. The regression includes store-byyear-by-month fixed effects and the structural characteristics that were described in Table 2. The store-by-year-by-month fixed effects provide the regression with flexible control over time and space. This is important since we have pooled housing observations across the country to conduct our analysis and the fixed effects force identification to come from spatial differences within a four mile area surrounding a Walmart. The regression includes three spatial indicator variables that indicate if a house is less than 0.5 miles, 0.5

\footnotetext{
${ }^{13}$ To calculate that a circle with a radius of 4 miles is $1 / 12^{\text {th }}$ the size of the median county, note that the median county size is approximately 622 square miles and the area of a 4 mile circle is approximately 50 square miles.
} 
to 1 mile, or 1 to 2 miles from the nearest Walmart. In the traditional hedonic framework, the coefficients on these indicators provide information about the marginal willingness to pay to live near a Walmart store.

Column (1) in Table 3 provides the coefficients and their standard errors for the three spatial indicator variables. The standard errors have been clustered at the Walmart store level. Taken literally, the coefficient on the within 0.5 mile indicator suggests that Walmarts in our sample reduce the prices of homes within 0.5 miles by approximately $2.5 \%$ (statistically significant at the 5\% level) and homes between 0.5 and 1 mile by a little less than $2 \%$ (statistically significant at the $10 \%$ level). Of course the concern with interpreting these estimates as the causal impact of Walmart on nearby housing prices is that they are likely to suffer from omitted variable bias. For example, if Walmart tends to open stores in areas that are less expensive for unobserved reasons (i.e. lower quality schools, the local landfill is nearby, further away from downtown, etc.) then these unobservable disamenities could potentially bias the traditional hedonic coefficients downwards.

\subsection{Difference-in-Differences Results}

To help mitigate the concern of omitted variable bias in our analysis we implement difference-in-differences regressions following Equation (2). The housing data used in this regression are restricted to houses within four miles of a Walmart that sold in the two and a half years after (just like in the cross-sectional analysis), but now we also include houses that sold in the two and a half years before the Walmart was built. The regression again includes store-by-year-by-month fixed effects and structural 
characteristics of the house that were described in Table 2. Besides the three spatial indicator variables that were included in the cross-sectional analysis, interactions of these indicators with an indicator for the house having sold after the Walmart opened are also included. The coefficients on these interaction indicators are of primary interest in the difference-in-differences analysis.

Column (2) in Table 3 provides the coefficients and their standard errors for the three spatial indicator variables and their interactions with the post-opening indicator variable. The standard errors have again been clustered at the Walmart store level. The coefficient on the "within 0.5 miles" indicator suggests that homes within a half mile of the future Walmart location sold for approximately 5\% less than homes two to four miles away. However, the coefficient on "within 0.5 miles*post" suggests that homes within 0.5 miles of the constructed Walmart store actually sold for approximately $2.5 \%$ more than baseline, after the Walmart was built. In other words, while homes within 0.5 miles of the future Walmart location sold for $5 \%$ less than homes 2 to 4 miles away, they only sold for $2.5 \%$ less after the Walmart was built. Similarly homes between 0.5 and 1 mile of the future Walmart sold for approximately 3\% less before the Walmart, but experienced an increase in sales prices of approximately one percentage point after the Walmart was built. Homes between 1 and 2 miles experience a small, but statistically insignificant increase in housing prices after the Walmart opening relative to the 2 to 4 mile control band.

Column (3) of Table 3 performs a heterogeneity check on our key findings in Column (2) by focusing the analysis on the 88 Walmart "supercenters" in our sample. ${ }^{14}$.

\footnotetext{
${ }^{14}$ A Walmart supercenter is typically larger than a regular Walmart store and also sells grocery items.
} 
The magnitude of the coefficient on the indicator "within 0.5 miles*post" is approximately the same in column (2). The biggest difference is that the coefficient on "0.5 to 1 mile*post" is twice as large as before suggesting that Walmart supercenters increase housing prices by approximately $2 \%$ for homes between one half and one mile after a Walmart supercenter opens.

Our Analysis thus far has been using a window of two and a half years before and after a Walmart opens for the inclusion of housing data in the regressions. In an ideal quasi-experiment for Walmart openings, the building of a Walmart would be announced one day and then the next day it would be built and operating. With this sharp discontinuity in time, one could potentially narrow the temporal window to something less than two and a half years before and after the opening of the nearest Walmart. However, the Walmarts in our sample took approximately one and a half years on average to be built after they were publicly announced. Therefore if there is some change in housing prices due to the announcement rather than the opening, narrowing the temporal window would cause the estimates to be attenuated. On the other hand, if we allow the temporal window to be very large, then we would be forced to drop many Walmarts from our sample since we analyze only Walmarts that have enough housing data around the opening date to create a symmetric temporal window. Since we only have housing data from 1998 to 2008 available to us, requiring five years of pre-opening housing data and five years of post-opening housing data would only allow us to use Walmart's that were built in 2003. Thus two and a half years was chosen to balance the tradeoff between excluding too many Walmarts and including enough housing sales that 
occurred before the announcement of the Walmart in an effort to mitigate the attenuation that may occur from the announcement effect.

Although from an experimental perspective it is nice to keep the temporal window for the inclusion of housing data symmetric around the Walmart opening date, one could potentially relax this to include Walmart stores in the analysis that have at least two and a half years of housing data before and after the opening, but then include housing observations that were temporally more distant than two and a half years before or after the opening. Column (4) shows the results of this difference-in-differences specification that does not exclude housing observations that are temporally more distant than two and a half years before or after the nearest Walmart's opening. The key coefficients are slightly larger with the within 0.5 mile*post coefficient suggesting an approximate 3.3 percent increase in housing prices and the 0.5 to 1 mile*post coefficient suggesting an approximate 2.3 percent increase.

One could also potentially widen or narrow the temporal window to check for robustness. Column (5) in Table 3 redoes the difference-in-differences analysis but widens the temporal window to include three years of housing data pre and post Walmart opening, while Column (6) narrows the temporal window to include only two years of housing data pre and post. The main findings are robust to these changes in the temporal window. The size of the coefficient on the "within 0.5 mile*post" indicator is slightly larger than in column (2) when the window is expanded to three years before and after, and slightly smaller when contracted to two years before and after. This is consistent with our earlier conjecture that if there is some change in housing prices due to the 
announcement or construction of the Walmart prior to the opening, narrowing the temporal window would cause the estimates to be attenuated downwards.

We can also more formally analyze whether or not there is an announcement effect on housing prices by applying our difference-in-differences analysis to the announcement date rather than the opening date. This time we include the housing data covering the two and a half years before and after the Walmart is announced. Column (7) of Table 3 shows the results of this analysis. The coefficient on "within 0.5 miles" shows once again that homes within a half mile of the future Walmart location sold for approximately $5 \%$ less than homes two to four miles away. The interaction of the postWalmart opening indicator for this distance suggests a $1.6 \%$ increase in housing prices although it is not statistically significant using conventional measures. The " 0.5 to 1 mile*post" coefficient suggests an approximate $1.4 \%$ increase in housing prices in the year after the announcement in this spatial zone and this result is statistically significant at the 5 percent level. These results are suggestive of there being some impact even from the announcement of the Walmart.

\subsection{Housing Composition Effects}

One issue with how we interpret the results we have found, has to do with whether or not the types of houses that are selling after a Walmart is built (or announced) are substantially different than the types of houses that were being sold previously. If there is a large compositional difference in the types of houses that transacted before and after, then this may signal that the housing price effects we observe are being at least partially driven by supply rather than demand. To be clear, this is still an impact of the 
Walmart being built (or announced), but it suggests that the estimates are not as tightly linked to household preferences and their perceptions about local externalities and the benefits of accessibility to shopping.

To explore the composition effects in this application, we ran a series of linear regressions with our key housing attributes on the left hand side and the distance to Walmart zone indicators and interactions on the right hand side. In these regressions we continued to control for store-by-year-by-month fixed effects and clustered the standard errors at the Walmart store level. Once again, the coefficients on the Walmart zone indicators interacted with the "post" time period are of primary interest as they will signal if there were substantial changes in these housing characteristics after the Walmart was built (or announced). Table 4 provides the results from these regressions. Panel A shows the results where we analyze changes in structural characteristics before and after Walmart opened, and Panel B shows the results where we analyze changes in structural characteristics before and after Walmart was announced. Of the 18 interaction coefficients that are estimated in Panel A, only one is statistically significant (at the 10\% level) suggesting there was no substantial housing composition change before and after Walmart opened. Of the 18 interaction coefficients estimated in Panel B, 3 are statistically significant at the $10 \%$ level but only 1 of those is significant at the $5 \%$ level. This lone coefficient suggests that there was an approximate 5\% decrease in new houses that were sold after the Walmart was announced in the 0 to 0.5 mile zone. Overall, these regressions do not seem consistent with strong housing composition effects before and after either a Walmart's opening or announcement. 
Another signal of potential instability in the marketplace caused by either the opening or announcement of a Walmart would be if there was an abrupt change in the number of homes that were being sold after the opening or announcement. To explore this hypothesis we analyzed the number of houses that transacted each quarter for the 10 quarters leading up to and the 10 quarters after the Walmarts in our sample opened. Figure 1 shows this graphically for each of the 4 spatial zones in our analysis relative to the opening date and the "approximate" announcement date. ${ }^{15}$ The natural log of the number of housing transactions by quarter is used so that each of the zones can be easily compared. ${ }^{16}$ As can be seen in Figure 1, the log number of houses in each area is gradually increasing over the time period and there do not appear to be any dramatic percentage changes or divergences between the 4 zones, suggesting that the housing markets were relatively stable over this time period.

\subsection{Graphical Analysis and Falsification Tests}

A key assumption in our difference-in-differences identification strategy is that within a localized four mile zone, Walmarts were not built in areas where there was a preexisting trend in housing prices. If for example, houses located within 1 mile of where a Walmart opened were experiencing faster growth in housing prices relative to homes in the 1 to 4 mile band, this could lead to estimating a spurious positive effect of Walmart openings in our difference-in-differences analysis. One way to better examine if there are

\footnotetext{
${ }^{15}$ The approximate announcement date is based on the median number of days between announcement and opening for the Walmart's in our sample.

${ }^{16}$ The 2-4 mile zone is substantially larger in area than the $0-0.5$ mile zone so it mechanically has many more housing transactions such that taking the natural log makes for an easier comparison. We also created a plot that shows the residuals from regressing the $\ln$ (number of house sales in a quarter) on quarter of the year from Walmart opening and by distance from the new Walmart which also reveals no significant change in house sales due to a Walmart opening.
} 
preexisting trends in the housing prices near where Walmart stores are built is to graphically illustrate housing price trends in the spatial zones before and after Walmart opens.

To provide this graphical evidence we first run a regression following Equation (2) using the data in our primary specification (Table 3, column (2)), but we leave out the spatial indicators and their interactions. We then aggregate the residuals by quarter of the year, for two and a half years before and after the Walmart opened, for each spatial zone (within 0.5 miles, 0.5 to 1 mile, 1 mile to 2 miles and 2 miles to 4 miles from the Walmart), relative to the opening date of the nearest Walmart. Figure 2 plots the residuals from this regression. The $\mathrm{y}$-axis ranges from -0.06 and 0.02 which represents an approximate 8 percentage point difference in housing prices. The $\mathrm{x}$-axis ranges from -10 to 10 which represents the ten quarters before the Walmart opened and the ten quarters after the Walmart opened. The vertical line in the center of the graph shows the timing of the opening date for the Walmarts in our sample. The vertical line at -5.67 illustrates the approximate announcement date that is based on the statistic reported earlier that the median time between announcement and the opening of a Walmart in our sample is 516 days.

The top two lines in Figure 2 show that the residuals for houses between one and four miles from the Walmart are generally close to zero and unchanging over the fiveyear period. The third line down represents the residuals of houses between a half and one mile from the nearest Walmart and it can be seen that they trend about -0.02 log price points lower until about one year before the nearest Walmart opens, and then they experience a slow rise. The fourth line down, representing the residuals of houses within 
0.5 miles of the Walmart, shows the most dramatic change from before and after the Walmart opens. The residuals start out around -0.04 until about one year before the Walmart opens and then there appears to be a dramatic increase in the residuals until they are near zero, two and a half years after the Walmart opens. Overall the residuals for the four zones are "fanned out" before the Walmart opens, are relatively steady until a year before the Walmart opens, and then they compress until they are nearly identical two and a half years after the Walmart opens. Given that it is likely to be apparent to homebuyers that a Walmart is being built two or three quarters before it is complete, this graphical evidence bolsters the argument that our difference-in-differences estimates are causal.

Figure 3 provides similar graphical evidence for the change in the residuals in the four spatial zones, before and after the Walmart was announced to be built. Again, before the announcement date there does not appear to be much of a trend in the residuals for any of the four zones. However, after the announcement of the new Walmart is made the residuals for the homes between 0.5 and 1 mile appear to begin trending upward and the homes within 0.5 miles trend upward even more rapidly.

Another check for whether or not the increase in housing prices after the opening of a Walmart is due to differential trends in housing prices between homes nearest the Walmart relative to housing prices farther away is to conduct a falsification test. We do this by estimating Equation (2) using our 2.5 year pre and post window but including false Walmart opening dates. The false opening dates are set to two years, two and a half years, and three years prior to the actual opening dates of Walmart. The results presented in Table 4 provide no evidence of a spurious, positive effect due to differential housing price growth at the Walmart location. Thus this falsification test in combination with the 
graphical analysis is supportive of a causal interpretation of our difference-in-differences estimates of the impact of Walmart on housing prices.

\section{Conclusion}

Although recent academic work has made it clear that the opening of a Walmart lowers retail prices for consumers in the area, there has been little work that systematically tests whether or not the opening of a Walmart lowers housing prices. In this paper we have attempted to answer this question. We compiled a unique dataset that linked micro-level housing data to 159 Walmarts that opened in the United States between 2000 and 2006. Exploiting the spatial resolution of the data we compared areas very near the Walmarts to areas slightly further away before and after the Walmarts opened. The results from our primary difference-in-differences specification suggest that a new Walmart store actually increases housing prices by between 2 and 3 percent for houses located within a half mile of the store and by 1 to 2 percent for houses located between a half and one mile from the store. For the average priced home in these areas this translates into an approximate $\$ 7,000$ increase in housing price for homes within a half mile of a newly opened Walmart and a $\$ 4,000$ increase for homes between a half and one mile.

Overall, the estimated capitalization effects that we find suggest a revealed preference by many households to live near a Walmart and the stores that naturally agglomerate nearby. On average, the benefits to quick and easy access to the lower retail prices offered by Walmart and shopping at these other stores appear to matter more to households than any increase in crime, traffic and congestion, noise and light pollution, 
or other negative externalities that would be capitalized into housing prices. This result is useful to policymakers that consider passing zoning regulations and other laws that could affect Walmart's ability to build new stores within their jurisdiction.

Although we in general find the results to be reasonably credible, some caveats should also be made. It is possible that while the accessibility benefits appear to extend out to at least a mile, there may still be negative externalities that affect households that live very close to a Walmart. Furthermore, our findings provide evidence that Walmarts increase housing values on average, but it is possible that in certain cases a new store may actually decrease housing values due to externalities. Finally, our estimates may be internally valid, but they may not be accurate in more rural areas, for example, where we do not have housing data. Examining the housing price impacts of Walmart in these other settings may be important to policymakers and could be looked at in future research. 


\section{References}

Basker, E. (2005a). "Job creation or destruction? Labor-market effects of Wal-Mart expansion. " Review of Economics and Statistics 87: 174-183.

Basker, E. (2005b). "Selling a cheaper mousetrap: Wal-Mart's effect on retail prices." Journal of Urban Economics 58: 203-229.

Basker, E. (2007). "The causes and consequences of Wal-Mart's growth." Journal of Economic Perspectives 21: 177-198.

Basker, E. and M. Noel (2009). "The evolving food chain: competitive effects of WalMart's entry into the supermarket industry." Journal of Economics and Management Strategy 18(4): 977-1009.

Black, S. (1999). "Do Better Schools Matter? Parental Valuation of Elementary Education." Quarterly Journal of Economics 114(2): 577-599.

Carden, A. and C. Courtemanche (2009). "Wal-Mart, leisure, and culture." Contemporary Economic Policy 27: 450-460.

Carden, A., C. Courtemanche and J. Meiners (2009a). "Does Wal-Mart reduce social capital?" Public Choice 138: 109-136.

Carden, A., C. Courtemanche and J. Meiners (2009b). "Painting the Town Red? WalMart and Values." Business and Politics 11 (Article 5).

Chay, K. and M. Greenstone (2005). "Does Air Quality Matter? Evidence from the Housing Market." Journal of Political Economy 113(2): 376-424.

Des Rosiers, F, A. Lagana, and . (1995). "Shopping centres and house values: an empirical investigation." Journal of Property Valuation and Investment January, 2002: 9-13.

Des Rosiers, F., A. Lagana, M. Thériault and M. Beaudoin (1996). "Shopping centres and house values: an empirical investigation." Journal of Property Valuation and Investment 14( 4): 41-62.

Emrath, P. (2002). "Explaining Housing Prices." Housing Economics January, 2002: 913.

Figlio, D. N. and M. E. Lucas (2004). "What's in a Grade? School Report Cards and the Housing Market." American Economic Review 94(3): 591-604.

Goetz, S. and A. Rupasingha (2006). "Wal-Mart and social capital." American Journal of Agricultural Economics 88: 1304-1310. 
Goetz, S. and H. Swaminathan (2006). "Wal-Mart and county-wide poverty." Social Science Quarterly 87: 211-226.

Hausman, J. and E. Leibtag (2007). "Consumer benefits from increased competition in Shopping centres and house values: an empirical investigation effect of WalMart." Journal of Applied Econometrics 22(7): 1157-1177.

Hicks, M. (2007a). "Job turnover and wages in the retail sector: the influence of Walmart." Journal of Private Enterprise 22: 137-159.

Hicks, M. (2007b). "Wal-Mart's Impact on Local Revenue and Expenditure Instruments in Ohio, 1988-2003." Atlantic Economic Journal, 35, 77-95.

Holmes, M. (2011). "The Diffusion of Wal-Mart and Economies of Density." Econometrica 79: 253-302.

Kuminoff, N. and J. Pope (2012). "'Rosen Bias' in the Willingness to Pay for Nonmarket Goods." mimeo.

Lim, J. and P. Missios (2007). " Does size really matter? Landfill scale impacts on property values." Applied Economic Letters. 14(10): 719-723.

Linden, L. and J. E. Rockoff (2008). "Estimates of the Impact of Crime Risk on Property Values from Megan's Laws." The American Economic Review 98(3): 1103-1127.

Neumark, D., J. Zhang and S. Ciccarella (2008). "The effects of Wal-Mart on local labor markets." Journal of Urban Economics 63: 405-430.

Pew Research Center for the People and the Press (2005). "Wal-Mart a Good Place to Shop But Some Critics Too. <http://people-press.org/report/265/wal-mart-a-goodplace-to-shop-but-some-critics-too $>$."

Parmeter, C. and J. Pope (forthcoming). "Quasi-Experiments and hedonic property value methods." Handbook on Experimental Economics and the Environment, eds. John A. List and Michael K. Price, Northampton, MA: Edward Elgar Publishing.

Pope, J. (2008). "Fear of Crime and Housing Prices: Household Reactions to Sex Offender Registries." Journal of Urban Economics 64(3): 601-614.

Palmquist, R.B. (2005). "Property Value Models." Handbook of Environmental Economics, edited by Karl-Göran Mäler and Jeffery R. Vincent. Amsterdam: North-Holland.

Ridker, R.G. and J.A. Henning (1967). "The Determinants of Residential Property Values with Special Reference to Air Pollution." Review of Economics and Statistics 49(2): 246-257. 
Rosen, S. (1974). "Hedonic prices and implicit markets: product differentiation in pure competition." Journal of Political Economy 82(1): 34-55.

Sirpal, R. (1994). " Empirical Modeling of the Relative Impacts of Various Sizes of Shopping Centers on the Values of Surrounding Residential Properties." Journal of Real Estate Research 9(4): 487-505.

Smith, V. K., C. Poulos, and H. Kim. (2002). "Treating Open Space as an Urban Amenity." Resource and Energy Economics 24: 107-29.

Sobel, R. and A. Dean (2008). "Has Wal-Mart buried mom and pop? The impact of WalMart on self employment and small establishments in the United States." Economic Inquiry 46: 676-695.

Tiebout, C. (1956). "A Pure Theory of Local Expenditures," Journal of Political Economy, 64(5), 416-424.

Vandegrift D., Loyer, J., and D. Kababik (2011). "The Effect of Walmart on the Tax Base: Evidence from New Jersey." Unpublished Manuscript. 
Figure 1: Log Counts of Housing Transactions by Distance to Walmart

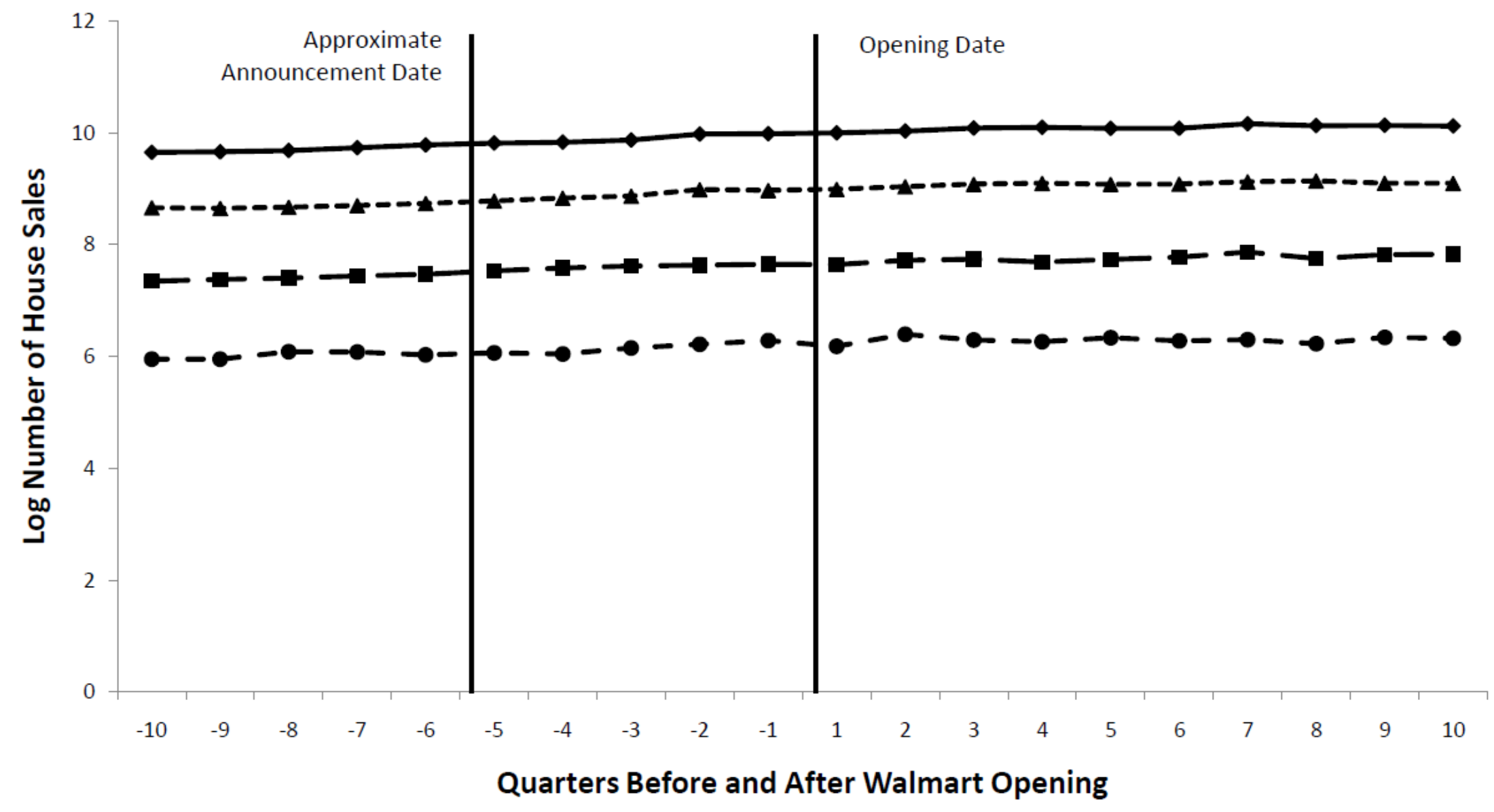

$\boldsymbol{C} 0$ to 0.5 miles $\longrightarrow 0.5$ to 1 mile $\quad-2$ to 4 miles

Note: Log counts have been aggregated by quarter for each of the 4 zones ( 0 to 0.5 miles, 0.5 to 1 mile, 1 to 2 miles, and 2 to 4 miles) around the 159 Walmarts in our sample. The x-axis shows the 2.5 years before (negative numbers) and 2.5 years after (positive numbers) the opening of a Walmart in quarters. 
Figure 2: Residual Plot of Log Price Regression Before and After Walmart Opening

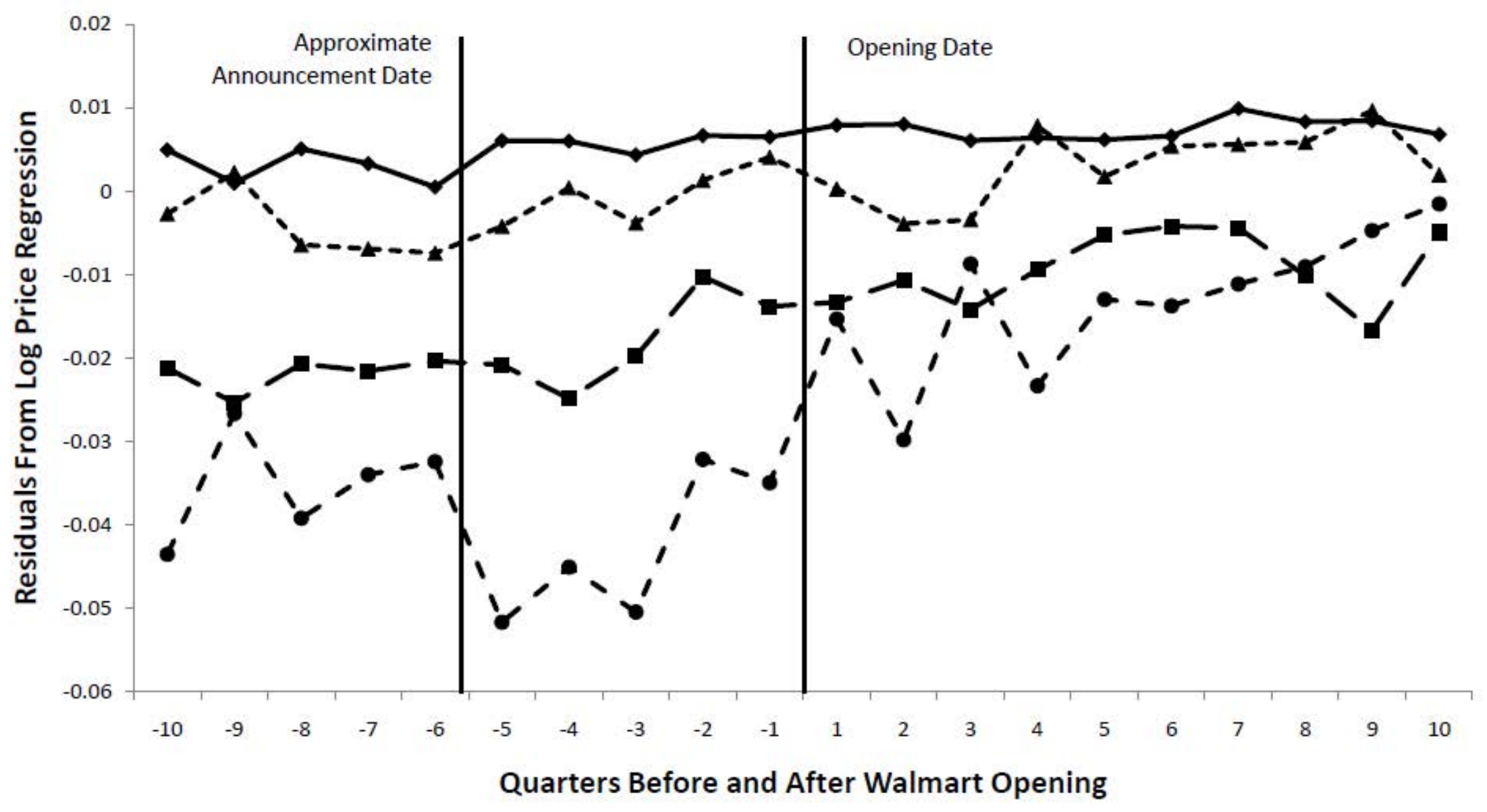

- 0 to 0.5 miles -0.5 to 1 mile -2 to 4 miles

Note: Residuals have been aggregated by quarter. The y-axis shows the residuals from regressing $\ln ($ price) on housing characteristics by quarter of the year from the event (Walmart opening) and by distance from the new Walmart ( 0 to 0.5 miles, 0.5 to 1 mile, 1 to 2 miles, and 2 to 4 miles). The $x$-axis shows the 2.5 years before (negative numbers) and 2.5 years after (positive numbers) the opening of a Walmart in quarters. 
Figure 3: Residual Plot from Log Price Regression Before and After Walmart Announcement

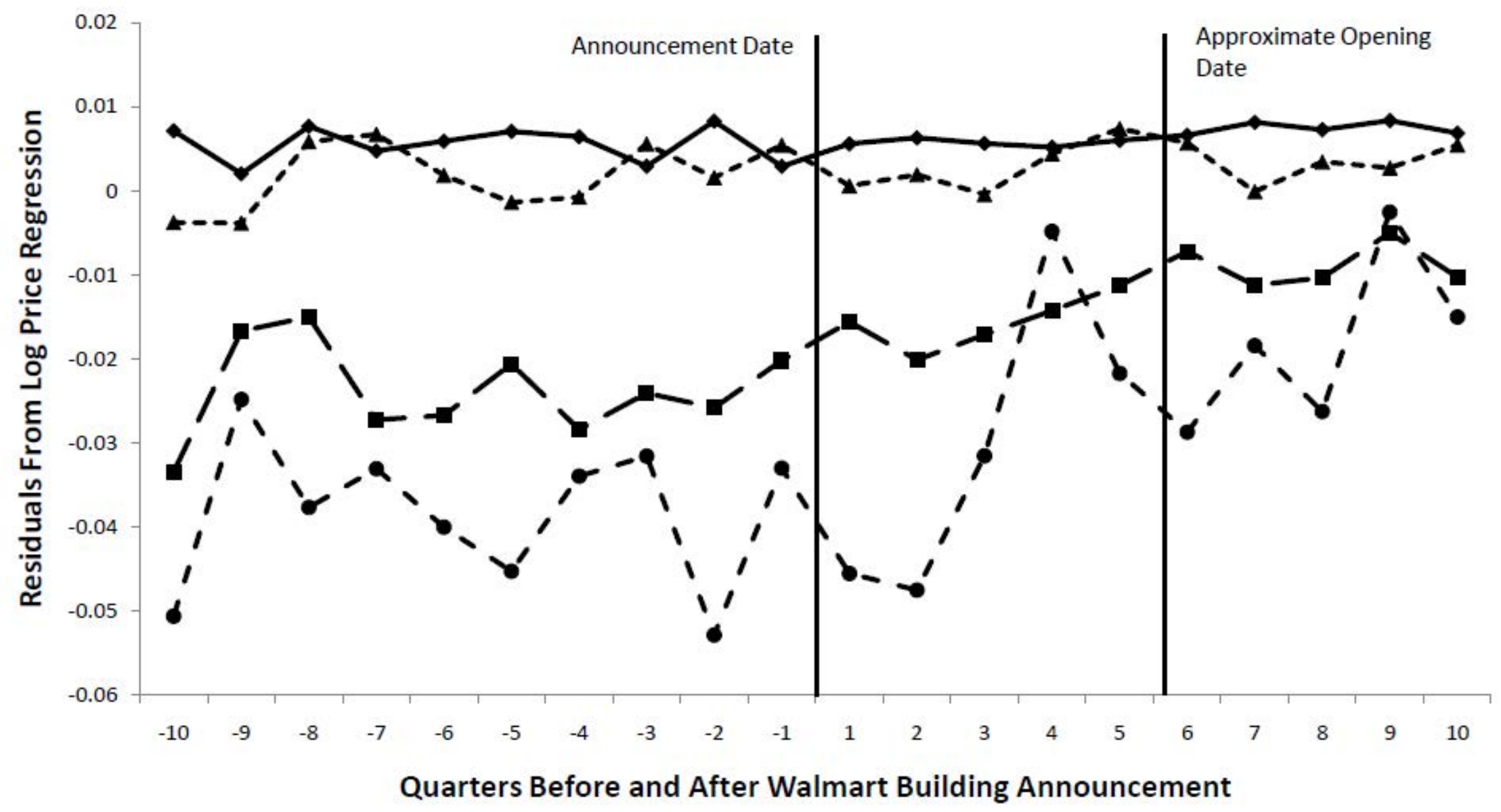

-0 to 0.5 miles 0.5 to 1 mile $\quad-\mathbf{A}=1$ to 2 miles 2 to 4 miles

Note: Residuals have been aggregated by quarter. The y-axis shows the residuals from regressing $\ln$ (price) on housing characteristics by quarter of the year from the event (Walmart announcement) and by distance from the new Walmart ( 0 to 0.5 miles, 0.5 to 1 mile, 1 to 2 miles, and 2 to 4 miles). The $x$-axis shows the 2.5 years before (negative numbers) and 2.5 years after (positive numbers) the announcement of a Walmart in quarters. 
Table 1: Tabulations of the Year, Month and State that Walmarts Opened

\begin{tabular}{|c|c|c|c|c|c|c|c|c|}
\hline \multicolumn{3}{|c|}{$\begin{array}{c}\text { PANEL A } \\
\text { Year Walmart Opened }\end{array}$} & \multicolumn{3}{|c|}{$\begin{array}{c}\text { PANEL B } \\
\text { Month Walmart Opened }\end{array}$} & \multicolumn{3}{|c|}{$\begin{array}{c}\text { PANEL C } \\
\text { State Walmart Opened }\end{array}$} \\
\hline Year & Freq. & Percent & Month & Freq. & Percent & State & Freq. & Percent \\
\hline 2000 & 7 & 4.4 & Jan. & 44 & 27.67 & CA & 36 & 22.64 \\
\hline 2001 & 22 & 13.84 & Feb. & 0 & 0 & CO & 13 & 8.18 \\
\hline 2002 & 34 & 21.38 & Mar. & 10 & 6.29 & CT & 14 & 8.81 \\
\hline 2003 & 29 & 18.24 & Apr. & 5 & 3.14 & DE & 1 & 0.63 \\
\hline 2004 & 34 & 21.38 & May & 14 & 8.81 & $\mathrm{FL}$ & 21 & 13.21 \\
\hline 2005 & 24 & 15.09 & June & 3 & 1.89 & MA & 8 & 5.03 \\
\hline \multirow[t]{2}{*}{2006} & 9 & 5.66 & July & 10 & 6.29 & MI & 1 & 0.63 \\
\hline & & & Aug. & 23 & 14.47 & $M N$ & 3 & 1.89 \\
\hline \multirow[t]{13}{*}{ Total } & 159 & 100 & Sept. & 11 & 6.92 & Mo & 1 & 0.63 \\
\hline & & & Oct. & 37 & 23.27 & NV & 8 & 5.03 \\
\hline & & & Nov. & 2 & 1.26 & NC & 6 & 3.77 \\
\hline & & & Dec. & 0 & 0 & $\mathrm{OH}$ & 10 & 6.29 \\
\hline & & & & & & OR & 2 & 1.26 \\
\hline & & & Total & 159 & 100 & PA & 17 & 10.69 \\
\hline & & & & & & RI & 1 & 0.63 \\
\hline & & & & & & SC & 2 & 1.26 \\
\hline & & & & & & TN & 1 & 0.63 \\
\hline & & & & & & VA & 5 & 3.14 \\
\hline & & & & & & WA & 8 & 5.03 \\
\hline & & & & & & WI & 1 & 0.63 \\
\hline & & & & & & Total & 159 & 100 \\
\hline
\end{tabular}

Note: Tabulations of the year, month and state for the 159 Walmarts that are in our primary sample. 
Table 2: Summary Statistics of Housing Data

\begin{tabular}{|c|c|c|c|c|}
\hline \multirow[t]{2}{*}{ Distance to Walmart: } & All Houses & 1 to 2 miles & 0.5 to 1 mile & Within 0.5 mile \\
\hline & $\begin{array}{c}\text { mean } \\
\text { (st. deviation) }\end{array}$ & $\begin{array}{c}\text { mean } \\
\text { (st. deviation) }\end{array}$ & $\begin{array}{c}\text { mean } \\
\text { (st. deviation) }\end{array}$ & $\begin{array}{c}\text { mean } \\
\text { (st. deviation) }\end{array}$ \\
\hline \multirow[t]{2}{*}{ Sale price } & 267,423 & 263,628 & 253,039 & 237,924 \\
\hline & $(188,323)$ & $(181,397)$ & $(161,573)$ & $(145,603)$ \\
\hline \multirow[t]{2}{*}{ Square footage } & 1,767 & 1,742 & 1,721 & 1,625 \\
\hline & (743) & (720) & (681) & (593) \\
\hline \multirow[t]{2}{*}{ \# of baths } & 2.198 & 2.196 & 2.201 & 2.087 \\
\hline & $(0.854)$ & $(0.856)$ & $(0.832)$ & $(0.759)$ \\
\hline \multirow[t]{2}{*}{ Age } & 30.116 & 30.300 & 28.487 & 29.069 \\
\hline & $(25.480)$ & $(25.936)$ & $(25.222)$ & $(24.312)$ \\
\hline \multirow[t]{2}{*}{ Lot size (in acres) } & 0.254 & 0.242 & 0.226 & 0.213 \\
\hline & $(0.327)$ & $(0.285)$ & $(0.262)$ & $(0.236)$ \\
\hline \multirow[t]{3}{*}{ \# of Bedrooms } & 3.198 & 3.186 & 3.199 & 3.134 \\
\hline & $(0.811)$ & $(0.807)$ & $(0.783)$ & $(0.756)$ \\
\hline & Percentage & Percentage & Percentage & Percentage \\
\hline New Sale & $15.29 \%$ & $15.07 \%$ & $16.28 \%$ & $11.70 \%$ \\
\hline Within 0.5 miles & $1.57 \%$ & $0 \%$ & $0 \%$ & $100 \%$ \\
\hline 0.5 to 1 mile & $6.64 \%$ & $0 \%$ & $100 \%$ & $0 \%$ \\
\hline 1 to 2 miles & $24.54 \%$ & $100 \%$ & $0 \%$ & $0 \%$ \\
\hline Sample size & 626,750 & 153,775 & 41,622 & 9,826 \\
\hline
\end{tabular}

Note: Summary statistics for all houses in our primary sample as well as summary statistics for areas closer to the locations of Walmarts in our sample. 
Table 3: Impact of Walmart Store Openings and Announcements on Property Values

\begin{tabular}{|c|c|c|c|c|c|c|c|}
\hline \multirow[t]{2}{*}{ Analysis Type: } & \multicolumn{6}{|c|}{ Walmart Opening } & \multirow{3}{*}{$\begin{array}{c}\text { Announcement } \\
2.5 \text { years } \\
\text { pre \& post }\end{array}$} \\
\hline & 2.5 years & 2.5 years & pre & $>=2.5 \mathrm{yrs}$ & 3 years & 2 years & \\
\hline \multirow[t]{2}{*}{ Temporal Selection: } & post & \multicolumn{2}{|c|}{ \& post } & pre \& post & pre $\&$ post & pre \& post & \\
\hline & $(1)$ & $(2)$ & $(3)$ & $(4)$ & (5) & (6) & $(7)$ \\
\hline$\underline{\text { VARIABLES }}$ & Inprice & Inprice & Inprice & Inprice & Inprice & Inprice & Inprice \\
\hline Within 0.5 miles & $\begin{array}{c}-0.0260 * * \\
(0.012)\end{array}$ & $\begin{array}{c}-0.0486 * * * \\
(0.013)\end{array}$ & $\begin{array}{c}-0.0504 * * * \\
(0.015)\end{array}$ & $\begin{array}{c}-0.0512 * * * \\
(0.013)\end{array}$ & $\begin{array}{c}-0.0502 * * * \\
(0.013)\end{array}$ & $\begin{array}{c}-0.0484^{* * *} \\
(0.013)\end{array}$ & $\begin{array}{c}-0.0496 * * * \\
(0.016)\end{array}$ \\
\hline Within 0.5 miles * post & & $\begin{array}{c}0.0237^{* *} \\
(0.010)\end{array}$ & $\begin{array}{c}0.0249 * \\
(0.013)\end{array}$ & $\begin{array}{c}0.0331 * * * \\
(0.009)\end{array}$ & $\begin{array}{c}0.0296 * * * \\
(0.009)\end{array}$ & $\begin{array}{c}0.0209 * * \\
(0.010)\end{array}$ & $\begin{array}{l}0.0155 \\
(0.010)\end{array}$ \\
\hline 0.5 to $1 \mathrm{mile}$ & $\begin{array}{c}-0.0178 * \\
(0.009)\end{array}$ & $\begin{array}{c}-0.0268^{* *} \\
(0.010)\end{array}$ & $\begin{array}{c}-0.0295^{* *} \\
(0.015)\end{array}$ & $\begin{array}{c}-0.0299 * * * \\
(0.011)\end{array}$ & $\begin{array}{c}-0.0255^{* *} \\
(0.011)\end{array}$ & $\begin{array}{c}-0.0243^{* *} \\
(0.011)\end{array}$ & $\begin{array}{c}-0.0338^{* *} \\
(0.013)\end{array}$ \\
\hline 0.5 to 1 mile $*$ post & & $\begin{array}{c}0.00942 * \\
(0.005)\end{array}$ & $\begin{array}{c}0.0187^{* *} \\
(0.008)\end{array}$ & $\begin{array}{c}0.0233^{* * *} \\
(0.007)\end{array}$ & $\begin{array}{c}0.0125^{* *} \\
(0.005)\end{array}$ & $\begin{array}{c}0.00746 \\
(0.005)\end{array}$ & $\begin{array}{c}0.0139 * * \\
(0.006)\end{array}$ \\
\hline 1 to 2 miles & $\begin{array}{c}-0.0051 \\
(0.007)\end{array}$ & $\begin{array}{c}-0.00878 \\
(0.008)\end{array}$ & $\begin{array}{c}-0.00712 \\
(0.011)\end{array}$ & $\begin{array}{r}-0.0089 \\
(0.009)\end{array}$ & $\begin{array}{c}-0.00812 \\
(0.009)\end{array}$ & $\begin{array}{r}-0.0081 \\
(0.008)\end{array}$ & $\begin{array}{c}-0.00611 \\
(0.009)\end{array}$ \\
\hline 1 to 2 miles * post & & $\begin{array}{c}0.004 \\
(0.004)\end{array}$ & $\begin{array}{c}0.00368 \\
(0.006)\end{array}$ & $\begin{array}{c}0.0103^{* *} \\
(0.005)\end{array}$ & $\begin{array}{c}0.00535 \\
(0.004)\end{array}$ & $\begin{array}{c}0.00373 \\
(0.003)\end{array}$ & $\begin{array}{c}0.00167 \\
(0.006)\end{array}$ \\
\hline Store by year by month fixed effects & $x$ & $x$ & $\mathrm{x}$ & $x$ & $\mathrm{X}$ & $\mathrm{x}$ & $x$ \\
\hline Store-level clustering of std. errors & $x$ & $x$ & $x$ & $x$ & $x$ & $x$ & $x$ \\
\hline Housing characteristics & $x$ & $x$ & $x$ & $x$ & $x$ & $x$ & $x$ \\
\hline Super walmart only & & & $x$ & & & & \\
\hline \# of walmart stores & 159 & 159 & 88 & 159 & 155 & 164 & 119 \\
\hline Observations & 358,076 & 626,750 & 347,371 & $1,481,811$ & 721,200 & 513,962 & 401,383 \\
\hline R-squared & 0.86 & 0.86 & 0.85 & 0.85 & 0.86 & 0.86 & 0.86 \\
\hline
\end{tabular}

Note: All but column (1) are DID regressions. Analysis type refers to whether the analysis is focused on housing prices before and after the Walmart opening date or the Walmart announcement date. The temporal selection of 2.5 years post means that only houses transacted in the 2.5 years after the Walmart opened are included. All other temporal selections refer to the years pre and post the Walmart opening (or announcement in the case of the announcement analysis). Standard errors are clustered at the store level. A* means the estimate is significant at the $10 \%$ level, ** at the $5 \%$ level and $* * *$ at the $1 \%$ level. 
Table 4: Housing Composition Regression Results

\begin{tabular}{|c|c|c|c|c|c|c|}
\hline \multirow[t]{2}{*}{ Panel A: } & \multicolumn{6}{|c|}{ Before and After Walmart Opening } \\
\hline & (1) & (2) & (3) & (4) & (5) & (6) \\
\hline VARIABLES & sqft & bath & age & lotacre & bedrms & new_sale \\
\hline Within 0.5 miles & $\begin{array}{c}-172.5^{* * *} \\
(37.000)\end{array}$ & $\begin{array}{c}-0.108^{* *} \\
(0.042)\end{array}$ & $\begin{array}{l}-1.713 \\
(1.431)\end{array}$ & $\begin{array}{c}-0.0655^{* * *} \\
(0.010)\end{array}$ & $\begin{array}{c}-0.0920 * * * \\
(0.032)\end{array}$ & $\begin{array}{c}0.00378 \\
(0.029)\end{array}$ \\
\hline Within 0.5 miles * post & $\begin{array}{c}-18.81 \\
(22.120)\end{array}$ & $\begin{array}{l}-0.0168 \\
(0.022)\end{array}$ & $\begin{array}{c}0.151 \\
(0.710)\end{array}$ & $\begin{array}{c}-0.00497 \\
(0.011)\end{array}$ & $\begin{array}{c}-0.01 \\
(0.020)\end{array}$ & $\begin{array}{l}-0.0396 \\
(0.030)\end{array}$ \\
\hline 0.5 to 1 mile & $\begin{array}{c}-110.3^{* * *} \\
(26.150)\end{array}$ & $\begin{array}{c}-0.0629 * * \\
(0.026)\end{array}$ & $\begin{array}{l}-0.695 \\
(1.114)\end{array}$ & $\begin{array}{c}-0.0488^{* * *} \\
(0.009)\end{array}$ & $\begin{array}{c}-0.0479 * * \\
(0.022)\end{array}$ & $\begin{array}{l}0.0245 \\
(0.017)\end{array}$ \\
\hline 0.5 to 1 mile * post & $\begin{array}{c}11.13 \\
(14.980)\end{array}$ & $\begin{array}{c}0.0294^{*} \\
(0.017)\end{array}$ & $\begin{array}{l}-0.575 \\
(0.622)\end{array}$ & $\begin{array}{c}-0.00331 \\
(0.004)\end{array}$ & $\begin{array}{l}0.0118 \\
(0.014)\end{array}$ & $\begin{array}{l}-0.0251 \\
(0.016)\end{array}$ \\
\hline 1 to 2 miles & $\begin{array}{c}-65.84^{* * *} \\
(19.490)\end{array}$ & $\begin{array}{c}-0.0342 * \\
(0.020)\end{array}$ & $\begin{array}{c}0.447 \\
(0.721)\end{array}$ & $\begin{array}{c}-0.0304^{* * *} \\
(0.007)\end{array}$ & $\begin{array}{c}-0.0454^{* * *} \\
(0.014)\end{array}$ & $\begin{array}{c}-0.000509 \\
(0.012)\end{array}$ \\
\hline 1 to 2 miles * post & $\begin{array}{c}6.73 \\
(12.200)\end{array}$ & $\begin{array}{l}0.0126 \\
(0.010)\end{array}$ & $\begin{array}{l}-0.461 \\
(0.395)\end{array}$ & $\begin{array}{c}-0.00122 \\
(0.004)\end{array}$ & $\begin{array}{l}0.0121 \\
(0.011)\end{array}$ & $\begin{array}{c}-0.00424 \\
(0.012)\end{array}$ \\
\hline Observations & 626,750 & 626,750 & 626,750 & 626,750 & 626,750 & 626,750 \\
\hline R-squared & 0.19 & 0.258 & 0.513 & 0.193 & 0.128 & 0.249 \\
\hline \multirow[t]{2}{*}{ Panel B: } & \multicolumn{6}{|c|}{ Before and After Walmart Announcement } \\
\hline & $\begin{array}{l}\text { (7) } \\
\text { sqft }\end{array}$ & $\begin{array}{l}\text { (8) } \\
\text { bath }\end{array}$ & $\begin{array}{l}\text { (9) } \\
\text { age }\end{array}$ & $\begin{array}{c}(10) \\
\text { lotacre }\end{array}$ & $\begin{array}{c}\text { (11) } \\
\text { bedrms }\end{array}$ & $\begin{array}{c}\text { (12) } \\
\text { new_sale }\end{array}$ \\
\hline Within 0.5 miles & $\begin{array}{c}-169.7^{* * *} \\
(32.190)\end{array}$ & $\begin{array}{c}-0.0845^{*} \\
(0.045)\end{array}$ & $\begin{array}{l}-2.651 \\
(1.626)\end{array}$ & $\begin{array}{c}-0.0578^{* * *} \\
(0.011)\end{array}$ & $\begin{array}{c}-0.0597^{*} \\
(0.031)\end{array}$ & $\begin{array}{l}0.0209 \\
(0.030)\end{array}$ \\
\hline Within 0.5 miles * post & $\begin{array}{c}-1.738 \\
(21.910)\end{array}$ & $\begin{array}{c}-0.0194 \\
(0.025)\end{array}$ & $\begin{array}{c}0.51 \\
(0.809)\end{array}$ & $\begin{array}{c}-0.00422 \\
(0.010)\end{array}$ & $\begin{array}{c}-0.00915 \\
(0.022)\end{array}$ & $\begin{array}{c}-0.0510^{* *} \\
(0.025)\end{array}$ \\
\hline 0.5 to 1 mile & $\begin{array}{c}-129.2^{* * *} \\
(27.400)\end{array}$ & $\begin{array}{c}-0.0669 * * \\
(0.030)\end{array}$ & $\begin{array}{l}-1.002 \\
(1.341)\end{array}$ & $\begin{array}{c}-0.0520 * * * \\
(0.010)\end{array}$ & $\begin{array}{c}-0.0508^{* *} \\
(0.025)\end{array}$ & $\begin{array}{c}0.0470 * \\
(0.024)\end{array}$ \\
\hline 0.5 to 1 mile * post & $\begin{array}{c}34.91^{*} \\
(20.520)\end{array}$ & $\begin{array}{c}0.0410^{*} \\
(0.023)\end{array}$ & $\begin{array}{l}-1.021 \\
(0.742)\end{array}$ & $\begin{array}{c}0.00501 \\
(0.006)\end{array}$ & $\begin{array}{l}0.0113 \\
(0.019)\end{array}$ & $\begin{array}{l}-0.0227 \\
(0.023)\end{array}$ \\
\hline 1 to 2 miles & $\begin{array}{c}-71.60 * * * \\
(19.200)\end{array}$ & $\begin{array}{l}-0.0306 \\
(0.023)\end{array}$ & $\begin{array}{c}0.386 \\
(0.909)\end{array}$ & $\begin{array}{c}-0.0287^{* * *} \\
(0.007)\end{array}$ & $\begin{array}{c}-0.0403^{* *} \\
(0.016)\end{array}$ & $\begin{array}{c}0.00689 \\
(0.011)\end{array}$ \\
\hline 1 to 2 miles * post & $\begin{array}{c}1.473 \\
(16.120)\end{array}$ & $\begin{array}{c}0.00354 \\
(0.014)\end{array}$ & $\begin{array}{l}-0.618 \\
(0.418)\end{array}$ & $\begin{array}{c}-0.00551 \\
(0.004)\end{array}$ & $\begin{array}{l}-0.0145 \\
(0.014)\end{array}$ & $\begin{array}{l}0.0105 \\
(0.015)\end{array}$ \\
\hline Observations & 401,383 & 401,383 & 401,383 & 401,383 & 401,383 & 401,383 \\
\hline R-squared & 0.182 & 0.265 & 0.481 & 0.206 & 0.116 & 0.25 \\
\hline
\end{tabular}

Note: These linear regressions put the housing characteristics on the left hand size and the distance to the Walmart zones and interactions on the RHS while continuing to control for store-by-year-by-month fixed effects. Standard errors are clustered at the Walmart store level and a * means the estimate is significant at the $10 \%$ level, $* *$ at the $5 \%$ level and $* * *$ at the $1 \%$ level. 
Table 5: Falsification Tests of Walmart Opening on Property Values

\begin{tabular}{|c|c|c|c|}
\hline \multirow{2}{*}{$\begin{array}{l}\text { Analysis Type: } \\
\text { \# of Years Open Date is Shifted: }\end{array}$} & \multicolumn{3}{|c|}{ Opening Date Falsification Tests } \\
\hline & $\begin{array}{l}3 \text { years } \\
\text { earlier }\end{array}$ & $\begin{array}{c}2.5 \text { years } \\
\text { earlier }\end{array}$ & $\begin{array}{l}2 \text { years } \\
\text { earlier }\end{array}$ \\
\hline & (1) & (2) & (3) \\
\hline VARIABLES & Inprice & Inprice & Inprice \\
\hline Within 0.5 miles & $\begin{array}{c}-0.0540 * * * \\
(0.017)\end{array}$ & $\begin{array}{c}-0.0571^{* * *} \\
(0.015)\end{array}$ & $\begin{array}{c}-0.0504^{* * *} \\
(0.014)\end{array}$ \\
\hline Within 0.5 miles * post & $\begin{array}{c}-0.00222 \\
(0.011)\end{array}$ & $\begin{array}{c}0.00785 \\
(0.009)\end{array}$ & $\begin{array}{c}0.00959 \\
(0.008)\end{array}$ \\
\hline 0.5 to 1 mile & $\begin{array}{c}-0.0398^{* *} \\
(0.015)\end{array}$ & $\begin{array}{c}-0.0363^{* * *} \\
(0.014)\end{array}$ & $\begin{array}{c}-0.0333^{* * *} * \\
(0.012)\end{array}$ \\
\hline 0.5 to 1 mile * post & $\begin{array}{c}0.00677 \\
(0.007)\end{array}$ & $\begin{array}{c}0.00461 \\
(0.007)\end{array}$ & $\begin{array}{l}0.0082 \\
(0.006)\end{array}$ \\
\hline 1 to 2 miles & $\begin{array}{c}-0.00162 \\
(0.011)\end{array}$ & $\begin{array}{r}-0.0127 \\
(0.011)\end{array}$ & $\begin{array}{c}-0.0119 \\
(0.009)\end{array}$ \\
\hline 1 to 2 miles * post & $\begin{array}{c}-0.000522 \\
(0.006)\end{array}$ & $\begin{array}{c}0.00413 \\
(0.006)\end{array}$ & $\begin{array}{c}0.00325 \\
(0.005)\end{array}$ \\
\hline Store by year by month dummies & $x$ & $x$ & $x$ \\
\hline Store-level clustering of std. errors & $x$ & $x$ & $x$ \\
\hline Housing Characteristics & $x$ & $x$ & $x$ \\
\hline \# of walmart clusters & 90 & 105 & 123 \\
\hline Observations & 257,904 & 314,302 & 396,289 \\
\hline R-squared & 0.859 & 0.853 & 0.848 \\
\hline
\end{tabular}

Note: These are the results from difference-in-differences specifications that move the opening date forward for a falsification test. The \# of years open date is shifted refers to how many years the open date is shifted forward. 